\title{
Ixazomib/Dexamethasone Regimen
}

National Cancer Institute

\section{Source}

National Cancer Institute. Ixazomib/Dexamethasone Regimen. NCI Thesaurus. Code C136273.

A chemotherapy regimen consisting of ixazomib and dexamethasone that is used for the treatment of plasma cell myeloma. 